\title{
SEJARAH DESA TAIPA KECAMATAN LEMBO KABUPATEN KONAWE UTARA TAHUN 1978-2017
}

\author{
Oleh \\ Jumriatin $^{2}$, H. Mursidin T. ${ }^{3}$
}

\begin{abstract}
ABSTRAK: Permasalahan pokok penelitian ini adalah: 1) Apa latar belakang terbentuknya Desa Taipa Kecamatan Lembo Kabupaten Konawe Utara?, 2) Bagaimana faktor-faktor pendukung terbentuknya Desa Taipa Kecamatan Lembo Kabupaten Konawe Utara?, 3) Bagaimana perkembangan Desa Taipa Kecamatan Lembo Kabupaten Konawe Utara tahun 1978-2017?.

Penelitian menggunakan metode penelitian sejarah yang terdiri atas 4 langkah-langkah sebagai berikut: 1) Pengumpulan sumber (heuristik) yaitu kegiatan peneliti untuk memperoleh data terkait judul penelitian, 2) Kritik sumber (verifikasi) yaitu untuk mengetahui otentitas (keaslian) dan kredibilitas (kebenaran) data yang berhasil dikumpulkan, 3) Penulisan sejarah (historiografi) yaitu menyampaikan sintesa dalam bentuk kisah sejarah. Dalam kajian pustaka penelitian ini menggunakan konsep sejarah, konsep desa, konsep terbentuknya desa, konsep administrasi pemerintahan, konsep pemekaran, dan konsep perkembangan serta penelitian yang relevan dengan judul penelitian ini.

Penelitian ini menunjukkan bahwa: 1) Latar belakang terbentuknya Desa Taipa merupakan keinginan masyarakat setempat untuk membentuk desa tersendiri. Yang memprakarsai terbentuknya Desa Taipa yakni para tokoh adat dan para tokoh masyarakat. Hal ini dilakukan karena untuk mendapatkan pelayanan yang lebih baik dalam bidang pemerintahan terutama dalam pelayanan pengurusan administrasi. 2) Faktor-faktor pendukung terbentuknya Desa Taipa Kecamatan Lembo Kabupaten Konawe Utara diantaranya: a) Jumlah penduduk, b) Luas wilayah, c) Potensi wilayah, e) Kondisi sosial budaya. 3) Perkembangan Desa Taipa Kecamatan Lembo Kabupaten Konawe Utara tahun 1978-2017 dapat dilihat dari: a) Perkembangan di bidang politik/pemerintahan diawali dengan terpilihnya Hasan B sebagai pelaksana b) Perkembangan di bidang sarana dan prasarana Desa Taipa dari tahun ketahun terjadi peningkatan, c) Perkembangan di bidang pelayanan umum yaitu pelayanan kependudukan, keamanan, dan perijinan d) Perkembangan di bidang ekonomi yaitu berupa penerimaan dana yang masuk dari desa seperti pajak dan ADD, dan e) Perkembangan di bidang pendidikan Desa Taipa mengalami peningkatan. Hal ini ditandai dengan adanya fasilitas pendidikan seperti TK dan SD.
\end{abstract}

\section{Kata Kunci: Latar Belakang, Faktor-faktor, Perkembangan}

\section{PENDAHULUAN}

Sejarah lokal yang identik dengan cerita rakyat sampai sekarang masih berkembang terus dan penyebarannya secara turun temurun oleh masyarakat. Tetapi masih banyak cerita rakyat yang belum terdeteksi maupun tersimpan dalam bentuk tulisan maupun kajian. Peristiwa-peristiwa yang terjadi di daerah biasanya dikenang dan diingat dalam bentuk nama. Nama tersebut biasanya diambil dari nama peristiwa, orang, binatang, tumbuhan dan sebagainya. Setiap desa memiliki sejarah berdirinya masing-masing dan memiliki ciri khas tersendiri yang membedakanya dengan yang lain. Seperti hal terbentuknya desa sebagai tempat tinggal kelompok terutama disebabkan karena naluri alamiah untuk mempertahankan kelompok. Didalam kelompok tersebut terjalin sendi-sendi yang melandasi hubungan-hubungan antara sesama warga kelompok berdasarkan hubungan kekerabatan/kekeluargaan, karena tinggal dekat dan karena kesamaan kepentingan.

Desa atau nama lainnya, sebagai sebuah entitas budaya, ekonomi, dan politik yang telah ada sebelum produk-produk hukum masa kolonial dan sesudahnya, diberlakukan, telah memiliki

\footnotetext{
${ }^{1}$ Disandur dari hasil penelitian

${ }^{2}$ Alumni Jurusan Pendidikan Sejarah

${ }^{3}$ Dosen FKIP UHO
} 
asas-asas pemerintahan sendiri yang asli, sesuai dengan karakteristik sosial dan ekonomi, serta kebutuhan dari rakyatnya. Konsep desa tidak hanya sebatas unit geografis dengan jumlah penduduk tertentu melainkan sebagai sebuah unit territorial yang dihuni oleh sekumpulan orang yang dengan kelengkapan budaya termasuk sistem politik dan ekonomi yang otonom.

Secara sosiologis, desa merupakan sebuah gambaran dan kesatuan masyarakat/komunitas penduduk yang bertempat tinggal dalam lingkungan dimana mereka saling mengenal dengan baik dan arah kehidupan mereka relatif homogen serta banyak bergantung pada alam. Komunitas di atas kemudian berkembang menjadi satu kestuan masyarakat hukum dimana kepentingan bersama penduduk diatur menurut hukum adat yang dilindungi dan dilambangkan. Ciri dari masyarakat hukum adat yang otonomi adalah yang berhak mempunyai wilayah sendiri dengan batas yang sah, berhak mengangkat bupati daerahnya/majelis sendiri berhak mempunyai sumber keuangan sendiri, serta berhak atas tanahnya sendiri.

Desa merupakan suatu wilayah yang dialami oleh sejumlah penduduk yang saling mengenal atas dasar hubungan kekerabatan dan/atau kepentingan politik, sosial ekonomi, dan keamanan yang dalam pertumbuhan menjadi kesatuan masyarakat hukum berdasarkan adat sehingga tercipta ikatan lahir dan batin antara masing-masing warganya, umumnya warganya hidup dari pertanian, mempunyai hak mengatur rumah tangga sendiri, dan secara administratif berada di bawah pemerintahan kabupaten/kota (Nurcholis, 2011: 4).

UU No.5 Tahun 1979, desa adalah suatu wilayah yang ditempati oleh sejumlah penduduk sebagai kesatuan masyarakat termasuk di dalamnya kesatuan masyarakat dan hukum yang mempunyai organisasi terendah langsung dibawah camat dan berhak menyelenggarakan rumah tangganya sendiri dalam ikatan Negara Kesatuan Republik Indonesia (Marbun, 2005: 99).

Setiap desa memiliki sejarah berdirinya masing-masing dan memiliki ciri khas tersendiri yang membedakanya dengan yang lain. Ada beberapa desa yang muncul karena daerah tersebut memiliki sumber daya alam yang melimpah dan ada juga yang lahir karena daerah tersebut memiliki sungai yang besar yang bisa dijadikan sebagai lalu lintas perdagangan yang dapat menghubungkan daerah yang satu dengan daerah yang lainya. Berdirinya suatu desa membutuhkan proses yang lama dan berkesinambungan.

Masyarakat pedesaan mempunyai hubungan yang lebih mendalam dari pada hubungan mereka dengan warga masyarakat pedesaan lainnya diluar batas-batas wilayahnya. Sistem kehidupan biasa berkelompok atas dasar sistem kekeluargaan. Penduduk masyarakat pada umumnya hidup dari pertanian cara bertani sangat tradisonal dan tidak efisien, karena belum dikenalnya mekanisme dalam pertanian. Biasanya mereka Bertani semata-mata untuk mencukupi kehidupan sendiri dan tidak untuk dijual (Soekanto, 2009: 145).

Desa Taipa di Kecamatan Lembo Kabupaten Konawe Utara adalah salah satu desa yang berada di Kabupaten Konawe Utara. Sejak awal terbentuknya Desa Taipa pada tahun 1978 telah menunjukan perkembangan diberbagai aspek kehidupan masyarakat. Pembentukan dan perkembangan Desa Taipa tidak terlepas dari perjuangn tokoh masyarakat serta dukungan aparat pemerintahan setempat dalam membangun wilayah Desa Taipa, dimana penduduk yang berada di Desa Taipa adalah mayoritas penduduk lokal dalam hal ini Suku Tolaki. Mata pencahariannya adalah bercocok tanam, berkebun tanaman jangka pendek dan panjang. Soestina dan Basah (1993: 90), mengemukakan bahwa pembentukan desa harus memenuhi syarat-syarat dengan memperhatikan faktor-faktor antara lain: (a) jumlah penduduk; (b) luas wilayah; (c) letak; (d) sarana dan prasarana; (e) sosial budaya; (f) kehidupan masyarakatnya.

Orang Tolaki yang berada di Desa Taipa dalam proses kegiatan pengolahan tanah sampai pada pemetikan hasil bercocok tanam dan berkebun tanaman jangka pendek dan jangka panjang merupakan kegiatan dari para anggota keluarga inti dan anggota kerabat lainnya secara gotong royong.

\section{METODE PENELITIAN}

Penelitian ini dilaksanakan di Desa Taipa Kecamatan Lembo Kabupaten Konawe Utara, dengan jenis penelitian sejarah yakni memberikan gambaran tentang Sejarah Desa Taipa Kecamatan Lembo Kabupaten Konawe Utara tahun 1978-2017 dan menggunakan pendekatan ilmu sosial dengan menekankan pada aspek strukturisnya yang mempelajari peristiwa dan struktur 
sebagai suatu kesatuan yang saling melengkapi. Artinya peristiwa mengandung penguatan mengubah hambatan atau dorongan bagi tindakan perubahan dalam masyarakat. Adapun model penulisanya yaitu menggunakan analisis sintesis (Hadara, 2014: 11-12).

Sumber data yang digunakan dalam penelitian ini mengacu pada tiga kategori sumber yaitu: sumber lisan, sumber tertulis, sumber visual. penelitian ini menggunakan metode penelitian sejarah yang dikemukakan oleh Sjamsuddin (2012: 96), yaitu (1) Heuristik (Pengumpulan Data), (2) Verifikasi (Kritik Sumber), dan (3) Historiografi. Prosedur atau tahap kerja sebagai berikut:

\section{HASIL PENELITIAN DAN PEMBAHASAN}

\section{Latar Belakang Terbentuknya Desa Taipa Kecamatan Lembo Kabupaten Konawe Utara}

Terbentuknya Desa Taipa Kecamatan Lembo Kabupaten Konawe Utara merupakan keinginan masyarakat setempat untuk membentuk desa tersendiri. Hal ini dilakukan karena untuk mendapatkan pelayanan yang lebih mudah dalam bidang pemerintahan terutama dalam pelayanan pengurusan administrasi. Desa Taipa di Kecamatan Lembo Kabupaten Konawe Utara diperkasai oleh para tokoh adat dan para tokoh masyarakat, diantaranya Bapak Hasan B, Bapak Pelesa, Bapak Tahir, Bapak Tahosa, Bapak Baco, Bapak H. Rahman, Bapak Ali, Bapak Rahama, Bapak Sunge, Bapak Sabahu, Bapak Duhu, Bapak Mukko, Bapak Hemma, Dan Bapak Adam. Merekalah para tokoh adat dan tokoh masyarakat yang memperjuangkan terbentuknya Desa Taipa definitif sebagai daerah otonom. Adanya keinginan tersebut merupakan naluria yang ada pada masyarakat untuk mengelola potensi wilayah yang ada dan untuk memudahkan masyarakat setempat untuk mendapatkan pelayanan yang mudah dalam urusan pemerintahan (Ahkam $\mathrm{H}$. Ali, SH, wawancara 24 Februari 2019).

Desa Taipa di Kecamatan Lembo Kabupaten Konawe Utara merupakan suatu desa yang berdiri menjadi daerah otonom pada tahun 1978 yang secara sah memisahkan diri dengan desa induk yakni Desa Sawah. Awal terbentuknya Desa Taipa menjadi daerah otonom sendiri dipimpin oleh seorang Kepala Desa yakni Bapak Hasan B sebagai pelaksana tetap. Berdasarkan hasil wawancara dengan salah seorang informan bahwa, Desa Taipa sebelum dimekarkan menjadi desa masih banyak terdapat jalan-jalan tanah atau jalan yang dibuat sendiri oleh masyarakat yang selalu bermasalah ketika datang musim hujan. Maka dengan terbentuknya Desa Taipa sebagai daerah otonom sendiri perlahan pemerintah setempat mulai memperbaiki infrastruktur yang ada $(\mathrm{H}$. Abubakar, wawancara 29 Januari 2019).

\section{Faktor-Faktor Pendukung Terbentuknya Desa Taipa Kecamatan Lembo Kabupaten Konawe Utara}

Terbentuknya Desa Taipa Kecamatan Lembo Kabupaten Konawe Utara merupakan pertimbangan yang berdasarkan pada keadaan geografis dan demografis wilayah Desa Taipa yang cukup berpotensi untuk dijadikan suatu desa yang mampu mengelola wilayahnya sendiri. faktorfaktor terbentuknya Desa Taipa Kecamatan Lembo Kabupaten Konawe Utara yaitu sebagai berikut:

\section{Faktor Jumlah Penduduk}

Jumlah penduduk merupakan salah satu faktor yang mendukung pembentukan desa, sesuai dengan peraturan menteri dalam negeri (Pemendagri) Nomor 28 tahun 2006 syarat alih suatu daerah mengalami pemekaran yakni salah satu adalah jumlah penduduk. Pada hakikatnya penduduk merupakan salah satu modal pembangunan nasional yang diharapkan dapat berpartisipasi dalam berbagai pembangunan bangsa. Kebijaksanaan kependudukan diarahkan pada peningkatan kualitas penduduk sebagai pelaku utama dan sasaran pembangunan nasional agar memiliki semangat kerja yang tinggi. Jumlah penduduk yang besar apabila dapat dibina dan dikerahkan sebagai tenaga kerja produktif yang berkualitas. Hal ini merupakan modal pembangunan yang handal dan dapat mendatangkan keuntungan bagi usaha pembangunan bangsa. Berdasarkan data awal peneliti bahwa jumlah penduduk Desa Taipa Kecamatan Lembo Kabupaten Konawe Utara pada awal terbentuk menjadi desa tersndiri pada tahun 1978 yaitu berjumlah 495 jiwa $(\mathrm{H}$. Abubakar, wawancara 29 Januari 2019). 


\section{Faktor Luas Wilayah}

Pertimbangan luas wilayah sangat mendukung terjadinya pemekaran disuatu wilayah. Luas wilayah dalam rangka pelaksanaan pemerintahan, baik tingkat negara, provinsi, kabupaten, kecamatan, maupun ditingkat desa/kelurahan merupakan suatu hal yang sangat penting. Dalam hal ini, luas wilayah Desa Taipa Kecamatan Lembo Kabupaten Konawe Utara yaitu seluas 457.00 km² atau 5,78 \% wilayah Kecamatan Lembo (Nasir, wawancara 25 Januari 2019).

\section{Faktor Potensi Wilayah}

Potensi wilayah merupakan salah satu aset yang dimilki oleh daerah untuk menunjang pembangunan nasional maupun daerah dalam mensejahterakan masyarakat. Dalam kaitan ini, potensi wilayah yang dimiliki oleh Desa Taipa Kecamatan Lembo Kabupaten Konawe Utara berpotensi untuk dijadikan sebagai areal pertanian. Hal ini dapat dibuktikan bahwa sebagaian besar mata pencaharian masyarakat Desa Taipa adalah sebagai petani yang berjumlah 320 jiwa orang. Desa Taipa sangat berpotensi untuk daerah perkebunan serta pertanian misalnya perkebunan kelapa, coklat, dan perkebunan buah-buahan Hal itu memiliki pengaruh besar terhadap perkembangan faktor ekonomi yang ada di Desa Taipa Kecamatan Lembo (H. Abubakar, wawancara 29 Januari 2019).

\section{Kondisi Sosial Budaya}

Sosial budaya merupakan faktor pendukung terbentuknya suatu desa dimana masyarakat setempat memiliki kekerabatan yang sangat menonjol dan tidak akan hilang. Sistem kekerabatan inilah yang masih dipegang teguh oleh masyarakat dan nilai budaya sangat dihormati dan dijunjung tinggi oleh masyarakat Desa Taipa, misalnya dalam memperingati hari-hari besar keagamaan dan ritual-ritual adat lainnya. Budaya juga merupakan faktor pendukung pembentukan suatu desa melalui kegiatan pembangunan dalam bidang sosial budaya diharapkan antara masyarakat yang ada di Desa Taipa baik yang beragam suku yang ada didalamnya maupun pemerintahan terjalin hubungan yang harmonis, hormat-menghormati, guna dalam menciptakan suasana yang harmonis dan kondusif sehingga dapat meningkatkan taraf hidup dan kesejahteraan masyarakat yang ada di Desa Taipa.

Kegiatan pembangunan dalam bidang sosial di Desa Taipa Kecamatan Lembo sudah terwujud sebelum Desa Taipa definitif. Pembanguna yang dimaksud seperti melalui saluran-saluran organisasi sosial. Organisasi sosial tersebut dimaksudkan sebagai wadah untuk menghimpun para warga masyarakat seluruh potensi yang dimiliki oleh daerah setempat, sehingga dikenal dengan sistem budaya saling membantu yang masih terwujud kelestariannya hingga sekarang ini. Yang diwujudkan dalam bentuk kerja sama, baik antara pemerintah maupun sesama anggota masyarakat setempat yang saling mendukung dalam perjuangan pembentukan Desa Taipa. Sistem budaya saling membantu ini sering dilakukan jika ada kegiatan-kegiatan apa saja dalam lingkup desa maupun sesama masyarakat sendiri, sehingga terwujud hubungan timbal balik yang harmonis dalam lingkup masyarakat (Nasir, wawancara 25 Januari 2019).

\section{Perkembangan Desa Taipa Kecamatan Lembo Kabupaten Konawe Utara Tahun 1978-2017}

Perkembangan dapat diartikan sebagai "proses yang kekal dan tetap yang menuju kearah suatu organisasi pada tingkat integrasi yang lebih tinggi, berdasarkan pertumbuhan, pematangan, dan belajar. Maksudnya perkembangan terjadi hanya sekali, dan tidak bisa diulang kembali. Karena pada dasarnya perkembangan selalu menuju ke arah yang lebih tinggi dibandingkan sebelumnya. Status perkembangan desa yang maju cenderung letaknya sangat dekat dengan pusat kegiatan. Hal ini relevan dengan penelitian Junaidi (2012: 72), bahwa perkembangan Desa Eks Transmigrasi juga ditentukan oleh jarak lokasi permukiman terhadap pusat-pusat kegiatan, sarana-prasarana, komoditas utama transmigrasi, karakteristik transmigran. Faktor kepadatan penduduk menjadi faktor penentu utama dalam penentuan status perkembangan desa.

\section{Perkembangan di Bidang Politik/Pemerintahan}

Politik adalah kegiatan suatu bangsa yang bertujuan untuk membuat, mempertahankan, dan mengamandemen peraturan-peraturan umum yang mengatur kehidupan, yang berarti tidak dapat terlepas dari gejala konflik dan kerja sama. Politik sebagai kegiatan yang berbuhungan dengan kendali pembuatan keputusan publik dalam masyarakat tertentu di wilayah tertentu, dimana kendali 
ini disokong lewat instrumen yang sifatnya otoritatif dan koersif. Dengan demikian, politik berkaitan erat dengan prosespembuatan keputusan publik.

Secara tradisional argumen keberadaan pemerintahan daerah lebih dititk beratkan pada kepentingan untuk mengetahui kondisi daerah untuk menangani persoalan-persoalan daerah secara efektif. Istilah sistem pemerintahan daerah berasal dari gabungan dua kata yaitu sistem dan pemerintahan daerah. Sistem berarti keseluruhan yang terdiri dari beberapa bagian yang mempunyai hubungan fungsional baik antara bagian-bagain maupun hubungan fungsional terhadap keseluruhannya, sehingga hubungan tersebut menimbulkan suatu ketergantungan antara bagianbagian yang akibatnya jika salah satu bagian tidak bekerja dengan baik akan mempengaruhi keseluruhannya itu.

Adapun perkembangan politik/pemerintahan Desa Taipa Kecamatan Lembo Kabupaten Konawe Utara dapat dilihat pada tabel berikut ini:

Tabel Nama-Nama Kepala Desa Taipa Kecamatan Lembo

\begin{tabular}{|c|l|c|}
\hline \multicolumn{1}{|c|}{ Nama Kepala Desa } & Keterangan \\
\hline 1978 & Hasan B. & Pelaksana \\
\hline 1979 & Sunge & Kepala Desa \\
\hline 2002 & Ahkam H. Ali & Kepala Desa \\
\hline 2007 & Burhan & Kepala Desa \\
\hline 2010 & Jus & Kepala Desa \\
\hline 2012 & H. Abubakar & Kepala Desa \\
\hline 2013 & Burhan & Kepala Desa \\
\hline 2018 & Ahkam H. Ali, SH & Kepala Desa \\
\hline
\end{tabular}

Sumber: Profil Desa Taipa, Tahun 2017

Berdasarkan tabel di atas menunjukan bahwa, perkembanganan politik/pemerintahan di Desa Taipa Kecamatan Lembo Kabupaten Konawe Utara diawali dengan terpilihnya Bapak Hasan B sebagai Kepala Desa pelaksana untuk desa yang memisahkan dari dari desa induknya. Desa Taipa Kecamatan Lembo Kabupaten Konawe Utara dibentuk berdasarkan keinginan masyarakat setempat untuk memimpin daerahnya dan mengelola sumber daya alam yang ada serta merupakan kesepakatan pemerintah kabupaten pada waktu itu yang didasari atas potensi daerah yang yang dimilikinya (Ahkam H. Ali, SH, wawancara 24 Februari 2019).

\section{Perkembangan di Bidang Sarana dan Prasarana}

Perkembangan suatu daerah akan berjalan dengan baik jika pemerintah setempat mampu membuat jalan desa yang menghubungkan akses jalan ke kabupaten. Hal ini untuk memudahkan arus transportasi, sehingga masyarakat setempat mampu memasarkan hasil produksi pertaniannya yang menjadi andalan dalam memenuhi kebutuhan seahari-hari.

Dalam menjunjung taraf hidup masyarakat Desa Taipa, pemerintah menyadari harus membangun sejumlah infrastrutur seperti fasilitas pendidikan misalnya sekolah dalam rangka mencerdaskan anak bangsa. Pemerintahan daerah otonom merupakan kesatuan masyarakat hukum yang mempunyai batas daerah tertentu, berwenang dan mengurus kepentingan masyarakat setempat menurut prakarsa sendiri. Sejalan dengan itu perkembangan Desa Taipa Kecamatan Lembo dalam bidang pelayanan masyarakat, dalam hal struktur pemerintah sudah cukup baik. Pemerintah juga membangun sarana pemerintahan sebagai pusat pelayanan, baik dibidang pengurusan administrasi kependudukan, maupun sosialisasi untuk kesehatan masyarakat.

Adapun perkembangan sarana dan prasarana Desa Taipa Kecamatan Lembo Kabupaten Kabupaten Konawe Utara dapat dilihat pada tabel berikut ini:

\section{Tabel. Perkembangan di Bidang Sarana dan Prasarana Desa Taipa}

\begin{tabular}{|c|c|l|c|}
\hline No & Tahun & \multicolumn{1}{|c|}{ Sarana dan Prasarana } & Keterangan \\
\hline 1. & 1957 & Pembangunan Masjid & Swadaya \\
\hline 2. & 1978 & Pembangunan Kantor Desa & APBD \\
\hline 3. & 1979 & Pembangunan SDN 3 Lembo & APBN \\
\hline 4. & 1999 & Pembangunan Gedung TK & PNPM \\
\hline 5. & 2000 & Pengerasan Jalan Desa & PNPM \\
\hline 6. & 2001 & Pengersan Jalan Dusun & PNPM \\
\hline 7. & 2005 & Pembuatan Embung & PNBD \\
\hline 8. & 2007 & Pembangunan Gedung Posyandu & \\
\hline
\end{tabular}




\begin{tabular}{|c|c|l|c|}
\hline 9. & 2015 & Pembangunan Kantor LPM & ADD \\
\hline 10. & 2015 & Pembangunan BUMDES & ADD \\
\hline
\end{tabular}

Sumber: Profil Desa Taipa, Tahun 2017

Berdasarkan keterangan tabel di atas, jelas bahwa perkembangan di bidang sarana dan prasarana Desa Taipa Kecamatan Lembo Kabupaten Konawe Utara pada tahun 1957 sampai dengan 2015 sudah memiliki sarana dan prasarana yang cukup memadai. Dimana dari tahun ketahun dapat dikatakan terjadi penambahan atau peningkatan jumlah sarana dan prasarana yang dibangun berdasrkan kebutuhan masyarakat setempat dengan melihat kondisi gegografis yang ada. Hal ini dilakukan untuk memudahkan masyarakat setempat untuk mengakses suatu informasi dan untuk memudahkan masyarakat dalam pelayanan administrasi atau urusan pemerintahan (Agus, wawancara 11 Februari 2019).

\section{Perkembangan di Bidang Pelayanan Umum}

Perkembangan pelayanan umum mencakup pelayanan pemerintah terhadap masyarakat. Sebagaimana salah satu tugas kepala desa adalah membina ketentuan dan ketertiban hidup masyarakat desa. Perkembangan pelayanan umum Desa Taipa Kecamatan Lembo Kabupaten Konawe Utara dapat dilihat pada tabel berikut:

Tabel. Kondisi di Bidang Pelayanan Umum Desa Taipa

\begin{tabular}{|r|c|c|c|}
\hline \multicolumn{1}{|c|}{ No } & Uraian & Keberadaan & Keterangan \\
\hline 1. & Pelayanan Kependudukan & Ada & $08.00-15.30$ \\
\hline 2. & Keamanan & Ada & 24 Jam \\
\hline 3. & Perijinan & Ada & 24 Jam \\
\hline
\end{tabular}

Sumber: Profil Desa Taipa, Tahun 2017

Berdasarkan tabel di atas maka jelas bahwa, pelayanan kependudukan Desa Taipa Kecamatan Lembo Kabupaten Konawe Utara dilaksanakan setiap jam kerja diantaranya pada pagi dan siang hari. Kadang kala ada penduduk yang datang pada sore hari. Dalam UUD RI tentang desa, telah disebutkan bahwa desa berkewajiban untuk memberikan dan meningkatkan pelayanan kepada masyarakat desa (Pasal 67,UU No. 6 Tahun 2006). Sementara itu, masyarakat desa berhak untuk memperoleh pelayanan yang sama dan adil (Pasal 68 UU No. 6 Tahun 2014).

Keamanan yang dimaksud adalah Satuan Linmas yang bertugas untuk menjaga kenyamanan dan keamanan masyarakat setempat dalam skala sedang dan besar yang dibantu oleh pihak yang berwajib untuk mententramkan masyarakat. Perijinan diantaranya adalah ijin keramaian dan ijin tinggal. Ijin keramaian diwajibkan bagi kegiatan yang bisa mendatangkan masa dalam jumlah banyak. Misalnya hiburan rakyat dan orjen. Ijin ini selain kepemerintah desa juga di teruskan ke Polri. Ijin tinggal diberlakukan kepada warga asing yang bertamu lebih dari 24 jam atau menginap terutama jika bukan keluarga dekat dengan warga setempat (Agus, wawancara 11 Februari 2019).

\section{Perkembangan di Bidang Ekonomi}

Sebagaimana yang tertuang dalam Undang-Undang Nomor 6 Tahun 2014 bahwa pendanaan desa bersumber dari: pendapatan asli desa terdiri atas hasil usaha, hasil aset, swadaya dan partisipasi, gotong royong dan lain-lain. Pendapatan asli Desa; alokasi anggaran pendapatan dan Belanja Negara; bagi hasil pajak daerah dan retribusi daerah Kabupaten/Kota; alokasi dana Desa yang merupakan bagian dari dana perimbangan yang terutama Kabupaten/Kota; hibah dan sumbangan yang tidak mengikat dari pihak ketiga; dan lain-lain merupakan pendapatan desa yang sah.

Kegiatan ekonomi pedesaan pada dasamya merupakan kehidupan yang seadanya yang mengolah dan memanfaatkan sumber daya alam setempat. Kegiatan ekonomi yang dilakukan di daerah pedesaan masih bersifat tradisional, dengan skala usaha yang kecil dan subsistem. Daerah pedesaan memiliki sumber daya alam potensial yang relatif banyak, tenaga kerja yang banyak dan murah. Tersedianya sumber daya alam yang banyak serta tenaga kerja yang murah merupakan faktor yang sangat meguntungkan bagi perkembangan ekonomi daerah yang bersangkutan. 
Tersedianya jumlah penduduk yang banyak merupakan pasar potensial. Hal ini sejalan dengan perkembangan ekonomi Desa Taipa Kecamatan Lembo Kabupaten Konawe Utara yang meningkat.

Adapun perkembangan ekonomi Desa Taipa Kecamatan Lembo Kabupaten Konawe Utara dapat dilihat dari tabel berikut ini:

Tabel 10. Perkembangan di Bidang Ekonomi Desa Taipa

\begin{tabular}{|c|c|c|c|c|c|c|}
\hline \multirow{2}{*}{ No } & \multirow{2}{*}{$\begin{array}{c}\text { Sumber } \\
\text { Penerimaan } \\
\end{array}$} & \multicolumn{5}{|c|}{ Tahun } \\
\cline { 3 - 7 } & Dana Desa & $\mathbf{2 0 1 3}$ & $\mathbf{2 0 1 4}$ & $\mathbf{2 0 1 5}$ & $\mathbf{2 0 1 6}$ & $\mathbf{2 0 1 7}$ \\
\hline 1. & Pajak & $4.613,000$ & $5.730,000$ & $5.730,000$ & $6.450,000$ & $7.875,000$ \\
\hline 2. & ADD & - & - & $133.263,000$ & $292.541,000$ & $491.645,000$ \\
\hline \multicolumn{2}{r}{ Jumlah } & $4.613,000$ & $5.730,000$ & 138.993 .000 & 298.991 .000 & 499.520 .000 \\
\hline
\end{tabular}

Sumber: Profil Desa Taipa, Tahun 2017

Berdasarkan tabel di atas menjelaskan bahwa, sumber penerimaan dana Desa Taipa tahun 2013-2017 berasal dari pajak dan ADD. Penerimaan pajak dari tahun 2013-2017 mengalami peningkatan. Adapun penyebab dari peningkatan penerimaan pajak selama tahun 2013-2017 karena banyaknya bangunan baru yang bertambah dan tarif pajak yang semakin tinggi. Sehingga dengan demikian banyaknya pendapatan yang diterima oleh daerah dapat digunakan untuk mensejahterakan masyarakat (Ahkam H. Ali, SH, wawancara 24 Februari 2019).

\section{Perkembangan di Bidang Pendidikan}

Sejalan dengan perkembangan ekonomi Desa Taipa Kecamatan Lembo Kabupaten Konawe Utara semakin meningkat, maka kepentingan-kepentingan keluarga mulai dapat terpenuhi dengan baik, bahkan anak-anak mereka sudah dapat menikmati pendidikan dengan baik dan sempurna. Mulai dari pendidikan TK, sampai pada tingkat perguruan tinggi terutam dilingkup Universitas. Perkembangan pendidikan di Desa Taipa pada khususnya dan Kecamatan Lembo pada umumnya mengalami perkembangan, dimana pendidikan yang boleh dikatakan sudah cukup baik. Terbukti dengan adanya sarana pendidikan yang terdapat di Desa Taipa seperti SD. Dengan adanya sarana pendidikan tersebut maka jumlah anak sekolah tiap tahunnya terus bertambah.

Melihat kenyataan yang ada, berarti kesadaran masyarakat akan arti pentingnya pendidikan sangat tinggi. Dalam hal ini kesadaran pihak orang tua untuk menyekolahkan anak-anaknya ke berbagai jenjang sudah cukup baik, ditambah dengan berbagai kemudahan serta kebijaksanaan pemerintah masalah pendidikan bagi masyarakat dibuktikan dengan adanya sarana dan prasarana yang berupa penambahan tenaga pengajar serta perlengkapan lainnya. Adanya kesadaran masyarakat yang demikian itu, dapat terlihat dari sikap dan pola pikir serta wawasan mereka terhadap masalah pendidikan. Masalah pendidikan tidak dapat dilepas atau dipisahkan dari kehidupan seseorang, dan pendidikan mempunyai hubungan secara langsung dengan kehidupan manusia. Karena dengan pendidikan manusia bisa memperoleh suatu penghidupan yang layak dalam memenuhi kebutuhannya. Pendidikan juga dapat mencerdaskan kehidupan bangsa (Ahkam H. Ali, SH, wawancara 24 Februari 2019).

\section{PENUTUP}

Berdasarkan uraian yang telah dikemukakan di atas, maka dapat ditarik beberapa simpulan yaitu sebagai berikut: (1) Latar belakang terbentuknya Desa Taipa di Kecamatan Lembo Kabupaten Konawe Utara merupakan keinginan para tokoh adat dan para tokoh masyarakat untuk membentuk desa tersendiri. Hal ini dilakukan karena untuk mendapatkan pelayanan yang lebih mudah dalam bidang pemerintahan terutama dalam urusan pelayanan administrasi. Terbentuknya Desa Taipa diperkasai oleh para tokoh adat dan para tokoh masyarakat, diantaranya Bapak Hasan B, Bapak Pelesa, Bapak Tahir, Bapak Tahosa, Bapak Baco, Bapak H. Rahman, Bapak Ali, Bapak Rahama, Bapak Sunge, Bapak Sabahu, Bapak Duhu, Bapak Mukko, Bapak Hemma, dan Bapak Adam. (2) Faktor-faktor pendukung terbentuknya Desa Taipa di Kecamatan Lembo Kabupaten Konawe Utara diantaranya: 1) Faktor jumlah penduduk. Jumlah penduduk merupakan salah satu faktor yang mendukung pembentukan desa, sesuai dengan Peraturan Menteri Dalam Negeri 
(Pemendagri) Nomor 28 tahun 2006 syarat alih suatu daerah mengalami pemekaran yakni salah satu adalah jumlah penduduk. Desa Taipa menurut data tahun 1978 tercatat dengan tingkat kepadatan penduduk sebesar 495 jiwa, 2) Faktor luas wilayah. Desa Taipa memiliki luas wilayah $457.00 \mathrm{Km}^{2}$, serta didukung oleh kondisi tanah yang cocok untuk dijadikan areal pertanian, 3) Faktor potensi wilayah. Potensi wilayah yang dimiliki Desa Taipa yaitu cocok untuk dijadikan sebagai areal pertanian, 4) Kondisi sosial budaya. Sistem budaya yang tetap melekat pada masyarakat Desa Taipa yaitu sistem budaya saling membantu ini sering dilakukan jika ada kegiatan-kegiatan apa saja dalam lingkup desa maupun sesama masyarakat sendiri, sehingga terwujud hubungan timbal balik yang harmonis dalam lingkup masyarakat. (3) Perkembangan Desa Taipa di Kecamatan Lembo Kabupaten Konawe Utara Tahun 1978-2017 dapat dilihat dari: 1) Perkembangan di bidang politik pemerintahan di Desa Taipa diawali dengan terpilihnya kepala Desa Taipa yakni Hasan B sebagai pelaksana, 2) Perkembangan di bidang sarana dan prasarana di Desa Taipa dari tahun 1978-2015 sudah memiliki sarana dan prasarana yang cukup memadai, 3) Perkembangan di bidang pelayanan umum di Desa Taipa meliputi pelayanan kependudukan, keamanan, dan perijinan, 4) Perkembangan di bidang ekonomi penerimaan dana Desa Taipa tahun 2013-2017 berasal dari pajak dan ADD, dan 5) Perkembangan di bidang pendidikan di Desa Taipa pada khususnya dan Kecamatan Lembo pada umumnya mengalami perkembangan pendidikan yang boleh dikatakan sudah cukup baik. Terbukti dengan adanya sarana pendidikan yang terdapat di Desa Taipa seperti TK dan SD.

\section{DAFTAR PUSTAKA}

Hadara, Ali. 2014. Prosedur Penelitian dan Penulisan Sejarah. Panduan Mahasiswa SI Pendidikan Sejarah, Kendari: Universitas Halu Oleo.

Marbun. 2005. Otonomi Daearh 1945-2005 Prosedur dan Realita (Perkembangan Otoda, Sejak Zaman Colonial Sampai Saat ini). Jakarta: Pustaka Sinar Harapan.

Nurcholis, Hanif. 2011. Pertumbuhan dan Penyelenggaraan Pemerintahan Desa. Jakarta: Erlangga.

Soestina dan Basah. 1993. Pokok-Pokok Pemerintahan di Daerah dan Pemerintahan Desa. Jakarta: Angkasa.

Sjamsuddin, Helius. 2016. Metodologi Sejarah. Yogyakarta: Ombak.

Soekanto, Soerjono. 2009. Sosiologi Suatu Pengantar. Jakarta: Rajawali Press. 